\title{
Impact of Aquatic Earthworms on Methane Emission Reduction from the Paddy Field Soil in Japan
}

\author{
Priyanka Mitra $^{1} \&$ Nobuhiro Kaneko ${ }^{1}$ \\ ${ }^{1}$ Graduate School of Environment and Information Sciences, Yokohama National University, Japan \\ Correspondence: Priyanka Mitra, Graduate School of Environment and Information Sciences, Yokohama \\ National University, 79-7, Tokiwadai, Hodogaya, Yokohama 240-8501, Japan. Tel: 81-45-339-4379. E-mail: \\ mitra-priyanka-nr@ynu.jp
}

\author{
Received: July 12, 2017 Accepted: August 16, $2017 \quad$ Online Published: September 15, 2017 \\ doi:10.5539/jas.v9n10p36 URL: https://doi.org/10.5539/jas.v9n10p36
}

The research was financed by Grant-in-Aid for Scientific Research (C) (Grant Number 65A0519) from The Ministry of Education, Culture, Sports, Science and Technology of Japan.

\begin{abstract}
Methane $\left(\mathrm{CH}_{4}\right)$ is one of the major greenhouse gases that significantly contributes to global warming. Therefore, substantial efforts are being made to reduce $\mathrm{CH}_{4}$ emissions. Paddy fields make a major contribution to atmospheric $\mathrm{CH}_{4}$ concentration because of their anoxic soil environment. Paddy field is habitat of many aquatic earthworms which can play a crucial role in reducing $\mathrm{CH}_{4}$ emissions from paddy field, because their bioturbation activities influence the soil structure and increase oxygen penetration and hence the activity of methanotrophs. Therefore, it was hypothesized that aquatic earthworms may accelerate oxidation of $\mathrm{CH}_{4}$ through their bioturbation activity. This incubation study evaluated the effects of earthworms on the activity of methanotrophs. Soil was incubated with a full factorial combination of two levels of aquatic earthworm (with and without earthworm) and two levels of fertilizer (with and without urea) for 35 days. The addition of urea increased the earthworm density in paddy soil by nearly doubled of without urea. At 28 days after incubation (DAI) the $\mathrm{CH}_{4}$ flux decreased from $2055 \mathrm{mg} \mathrm{m}^{-2} \mathrm{~h}^{-1}$ in only urea received soil to $425 \mathrm{mg} \mathrm{m}^{-2} \mathrm{~h}^{-1}$ in soil received both urea and earthworm treatment. Phospholipid fatty acid analysis showed that the presence of aquatic earthworms contributed to an increase in the biomass of methanotrophs. The study implies that aquatic earthworms may play vital role to reduce $\mathrm{CH}_{4}$ emission form paddy fields by creating favorable environment for methanotrophs, even in the soils fertilized with urea.
\end{abstract}

Keywords: bioturbation, Branchiura sowerbyi, urea, PLFA analysis, methanotrophs

\section{Introduction}

The Paris Agreement has set a target to limit global warming to well below $2{ }^{\circ} \mathrm{C}$ (UNFCCC, 2015). Diversified efforts and actions to reduce emissions of major greenhouse gases (GHGs) are critical to achieve this ambitious, but important target. Methane $\left(\mathrm{CH}_{4}\right)$ is one of the most potent GHGs as its contribution to the greenhouse effect is almost half of that of carbon dioxide $\left(\mathrm{CO}_{2}\right)$, even though the atmospheric concentration of $\mathrm{CH}_{4}$ is $1.8 \mathrm{ppm}$, lower than that of $\mathrm{CO}_{2}$ (399 ppm) (Gavin, 2004; Blasing, 2016). $\mathrm{CH}_{4}$ has been recognized as the second most important GHG after $\mathrm{CO}_{2}$, because of its higher global warming potential, which is 25 times higher than $\mathrm{CO}_{2}$ (Shindell et al., 2009). A recent report showed, over the last 200 years, the atmospheric $\mathrm{CH}_{4}$ concentration increased to double (Blasing, 2016). Wetland paddy fields significantly contribute to $\mathrm{CH}_{4}$ emission, which is equivalent to $11 \%$ of total emission (Smith et al., 2007).

Rice is the staple food of more than half of the world's population, which is mainly grown in flooded field condition (Kögel-Knabner et al., 2010). Continuous flooding condition for over the rice cultivation period leads to the anoxic soil environment, which favors growth of unique microbial communities (Yao et al., 1999; Lüdemann et al., 2000; Kögel-Knabner et al., 2010). In absence of oxygen, biodegradation of organic matter results in the methanogenesis, which is the main terminal microbiological process in anoxic environment (Thauer, 1998). 
The major methanogenic substrates are molecular hydrogen $\left(\mathrm{H}_{2}\right), \mathrm{CO}_{2}$, formate, acetate, methyl alcohol, and methylamine; the dominant reactions of methanogenesis in soil are the reduction of $\mathrm{CO}_{2}$ using molecular $\mathrm{H}_{2}$ and the transmethylation of acetate (Takai, 1970). During methanogenesis, carbon substrates are supplied to soil from soil organic matter, sloughed tissues of rice plants, applied organic matter, and root exudates (Watanabe et al., 1999; Kimura et al., 2004). Methanotrophs consume some of the $\mathrm{CH}_{4}$ produced under oxidative conditions in the rhizosphere of rice plants and in the thin layer where the soil and surface water meet (Dubey, 2005). The rest of the produced $\mathrm{CH}_{4}$ is released from paddy fields into the atmosphere via diffusion, ebullition from soil, and by diffusion and mass flow through the continuous intercellular gas space system between the rice rhizosphere and leaves. Inubushi et al. (1989) reported that $90 \%$ of total $\mathrm{CH}_{4}$ from paddy field is released through rice plant and ebullition and diffusion from soil contributes $10 \%$ and $<1 \%$, respectively. The physiological structure of rice plants favors greater emissions of $\mathrm{CH}_{4}$. A path of gaseous exchange exists between the root zone and atmosphere; intercellular channels through the aerenchyma connect the rhizosphere to the leaves, where gases are released into the atmosphere via stomata in the leaves and micropores in the leaf sheaths. In submerged paddy fields, this allows the diffusion of $\mathrm{CH}_{4}$ from the roots, to higher parts of the plant and then into the atmosphere (Nouchi et al., 1990).

Above discussions revealed that methanogenesis is the main process of $\mathrm{CH}_{4}$ formation in the wetland rice field and dropping of oxygen supply is one of the main factors to stimulate this process. There are many management measures including change in tillage practice, modify irrigation and drainage practice, change of nutrient supply sources has been tested and found some potential measures to improve oxidation status of soil environment of wetland paddy field. For example, a single mid-season drainage results in significant reduction of $\mathrm{CH}_{4}$ emissions (Kimura et al., 1992; Minamikawa et al., 2005). However, this management system increases emission risk of $\mathrm{N}_{2} \mathrm{O}$ (Bronson et al., 1997; Chen et al., 1997; Suratno et al., 1998). In a study, Yagi and Minami (1990) reported that chemical fertilizers strongly affect $\mathrm{CH}_{4}$ emissions from paddy field soils. Urea is the most widely used nitrogenous fertilizer for growing wetland rice because it is easy to handle and reasonably priced (Jones et al., 2013). In 1961, worldwide consumption of urea was 2 million tons, whereas in 1998, worldwide consumption of urea was 86 million tons (Soh, 2001). Use of huge amount of urea for growing rice may have impact on $\mathrm{CH}_{4}$ emission from paddy fields. Number of studies has been conducted to evaluate urea's impact on $\mathrm{CH}_{4}$ emission in paddy fields. However, the effects of urea on $\mathrm{CH}_{4}$ emissions from soils were found to be context-dependent. In some studies, $\mathrm{CH}_{4}$ emissions increased with increasing urea application rates because of increasing soil $\mathrm{pH}$ and ammonium inhibited the growth of methanotrophs (Wang et al., 1992; Dubey et al., 2003). In contrast, other study reported that ammonium enhanced oxidation of $\mathrm{CH}_{4}$ and the activities of methanotrophs (Bodelier et al., 2000).

Aquatic earthworms are a major group of invertebrate fauna in paddy field ecosystems and maintain soil quality (Simpson et al., 1993). More specifically, aquatic earthworms in paddy soils improve soil health by stimulating the release of $\mathrm{NH}_{4}{ }^{+}-\mathrm{N}$ from the surface waters to the soils (Kikuchi \& Kurihara, 1977, 1982; Fukuhara et al., 1980; Grant \& Seegers, 1985) as well as $\mathrm{PO}_{4}{ }^{3-}$ (Kikuchi \& Kurihara, 1982). The earthworm gut and fresh cast of earthworms accelerate activity of methanogens (Depkat-Jakob et al., 2012). On the other hand, burrows made by earthworms may aerate the soil and stimulate methanotrophic activity (Kernecker et al., 2015). The bioturbation activity of aquatic earthworms affects microorganism community by enhancing oxidation (Yingst \& Rhoads, 1980). Thus, aquatic earthworms may mitigate $\mathrm{CH}_{4}$ emissions from flooded paddy soils through inhibiting methanogenesis process and stimulating growth of $\mathrm{CH}_{4}$-consuming methanotrophs, a biological sink of $\mathrm{CH}_{4}$. However, there has been no study conducted to examine the effect of aquatic earthworms in $\mathrm{CH}_{4}$ emission from wet land paddy fields. It is also important to consider effect of fertilizer application on earthworms. However, low concentration of urea was reported as positive and beneficial for earthworm growth (Xiao et al., 2004).

Considering the above-mentioned background, we hypothesized that controlled application of urea and bioturbation activity by aquatic earthworms would enhance the biomass of methanotrophs, ultimately leading to a decrease in $\mathrm{CH}_{4}$ emissions. To test this hypothesis, we designed a research study with a full factorial combination of two aquatic earthworm levels (with earthworm and no earthworm) and two levels of fertilizer (with urea and no urea). As of our knowledge, this is the first study, which examined potential role of aquatic earthworms in $\mathrm{CH}_{4}$ mitigation process. The main objectives of our study were as follows:

(i) To investigate effect of urea application on abundance of aquatic earthworms and $\mathrm{CH}_{4}$ emission.

(ii) To see effect of aquatic earthworms on methanotrophs and $\mathrm{CH}_{4}$ emission from wetland paddy soil. 


\section{Method}

\subsection{Soil Preparation}

The laboratory experiment was conducted in Soil Ecology Laboratory of Yokohama National University, Japan. A 2X2 factorial experiment with 6 replications was designed involving two levels in the aquatic earthworm treatment: the presence or absence of aquatic earthworms (EW and NW, respectively), and two levels of urea treatment (UR and NU, respectively). Soil was collected from a paddy field in Kamakura, Kanagawa $\left(35^{\circ} 20^{\prime} \mathrm{N}\right.$, $139^{\circ} 31^{\prime} \mathrm{E}$; 56 m.a.s.l.). The soil contained $40 \%$ sand, $58 \%$ silt, and $2 \%$ clay. The soil was sun-dried, plant debris and stones were removed, and then the soil was sieved using $2 \mathrm{~mm}$ sieve to achieve a homogenous texture. A $100 \mathrm{~g}$ of soil was added in each of 24 transparent glass bottles. Then $120 \mathrm{ml}$ water was poured on soil in each bottle.

\subsection{Collection of Aquatic Earthworms}

Aquatic earthworms (Branchiura sowerbyi Beddard, 1892, Clitellata, Tubificidae) were collected from the flooded paddy soil, because it is one of the most dominant aquatic earthworm species in the paddy field (Yachi et al., 2012). The paddy soil was flooded for 8 weeks before collecting aquatic earthworms. To collect aquatic earthworms, muddy soils were sieved by a $500-\mu \mathrm{m}$ mesh sieve. The earthworms were kept in deionized water for $48 \mathrm{~h}$ to excrete intestinal residues. Then, the live earthworms were placed on filter paper to remove extra water from the body and each earthworm was weighed to record their biomass. Collected aquatic earthworms were incubated in soil for 7 days.

\subsection{Experimental Set-Up}

Rice straw powder $\left(2500 \mathrm{~kg} \mathrm{ha}^{-1}\right)$ was added to soil in each bottle as a source of organic matter and mixed gently using a spoon. As fertilizer treatment, granular urea $(46 \% \mathrm{~N})$ was added in respective 12 bottles at a rate of $90 \mathrm{~kg}$ $\mathrm{N}$ ha ${ }^{-1}$. Pre-incubated 6 earthworms were inoculated in six urea treated bottles and six no-urea treated bottles. Number of inoculated aquatic earthworms was decided based on representative density of earthworms in the Kamakura paddy field (unpublished data), which was 2525 earthworms $\mathrm{m}^{-2}$.

All bottles were incubated at $25{ }^{\circ} \mathrm{C}$ temperature and under 14 hours photoperiod to provide a nearly natural lighting environment for the earthworms for 35 days. At the end of the incubation period, the aquatic earthworms were collected from the soil in the bottles by sieving through a $500-\mu \mathrm{m}$ mesh size sieve and the numbers and biomass of earthworms were recorded.

\subsection{Gas Sampling and $\mathrm{CH}_{4}$ Measurement}

Gas samples were collected once per week, starting from day 0 , during the experiment. The first sample was collected $2 \mathrm{~h}$ after preparing the soil and the bottles were placed in the sampling area $30 \mathrm{~min}$ before sampling. Then, the mouth of each bottle was closed with a rubber septum that had plastic lids running from it (to collect the gas produced). The first gas sample was collected $10 \mathrm{~min}$ after closing a bottle, and then after 20 and $30 \mathrm{~min}$, with a plastic disposable $50 \mathrm{ml}$ syringe. Gas samples were collected into 30-ml glass vials. Methane concentration was measured using a gas chromatograph (GC-2014, SHIMADZU, Japan) and $\mathrm{CH}_{4}$ flux was calculated using the flux package (Jurasinski et al., 2014) in R software (R Development Core Team, 2015).

\subsection{Monitoring Soil Properties}

Each week soil $\mathrm{pH}$ and soil oxidation reduction potential (Eh) were measured at $1 \mathrm{~cm}$ and $5 \mathrm{~cm}$ depth from surface immediately after gas sample collections. Soil $\mathrm{pH}$ and Eh were measured using pH/COND Meter D-54 instrument (Horiba, Kyoto, Japan) and a pH/ORP/DO Meter D-75 instrument (Horiba, Kyoto, Japan), respectively.

\subsection{Measuring Soil Properties at the End of Incubation Period}

After collection of the final gas sample, soil samples were collected to measure total carbon (T-C) and total nitrogen (T-N). Collected samples were oven-dried at $40^{\circ} \mathrm{C}$ for $48 \mathrm{~h}$, and then T-C and T-N were measured using a CN Macro Corder (JM1000CN, J-Science Lab. Kyoto, Japan).

\subsection{Phospholipid Fatty Acid (PLFA) Analysis}

A phospholipid fatty acid (PLFA) analysis was conducted to determine the biomass of methanotrophs in this experiment. Lipids were extracted using a method modified from Frostegård et al. (1991), and Niwa et al. (2008). Briefly, lipids were extracted from 7-8 g fresh wet soil samples in a one-phase chloroform-methanol-phosphate buffer. After condensation of the lipids, the phospholipids were fractionated using a silicic acid column (BOND ELUT LRC-SI; Varian, Palo Alto, CA, USA) and then fatty acid methyl esters were separated from the 
phospholipids after mild alkaline methanolysis. An internal standard, methyl nonadecanoate (19:0), was added to all samples. Fatty acid methyl esters were identified using the Sherlock Microbial Identification System (MIDI,

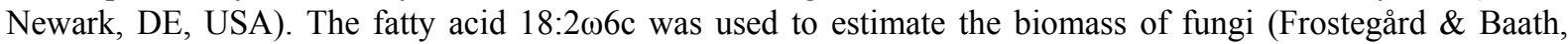
1996); 15:0iso, 15:0antesio, and 17:0iso were used to estimate the Gram-positive bacteria (Olsson \& Alström, 2000; Moore-Kucera \& Dick, 2008); and 17:0cyclo was used to estimate the Gram-negative bacteria (Wilkinson, 1988). The lipid biomarkers of methanotrophs often overlap with other groups, but in this study the fatty acid $16: 1 \omega 7 \mathrm{c}$ and $16: 1 \omega 5 \mathrm{c}$ were used to estimate the biomass of type I methane-oxidizing bacteria and $18: 1 \omega 7 \mathrm{c}$ was used to estimate the biomass of type II methane-oxidizing bacteria (R. S. Hanson \& T. E. Hanson, 1996; Bodelier et al., 2009; Zigah et al., 2015).

\subsection{Statistical Analysis}

The homogeneity of variance and normality of the data collected were determined with Bartlett's test and the Shapiro-Wilk test, respectively. When required, data were log-transformed to meet the assumptions of normality. The main and interaction effects of fertilizers and aquatic earthworms were assessed by generalized linear model (GLM) with Gamma distribution. The effects of the aquatic earthworms on the biomass of methanotrophs were assessed by two-way ANOVA. Statistical analyses were performed using R 3.2.3 for Microsoft Windows (R Development Core Team, 2015) using the package lme4 (Bates et al., 2015) to fit the model.

\section{Result and Discussion}

\subsection{Soil Environment}

The soil Eh value was higher at $1-\mathrm{cm}$ than at $5-\mathrm{cm}$ below soil surface irrespective of treatments throughout the incubation period (Table 1). At $1 \mathrm{~cm}$ below soil surface, Eh value was recorded between $-35 \mathrm{mV}$ to $-73 \mathrm{mV}$, indicated oxidation reduction potential is much higher than required Eh value to initiate methanogenesis process. In principle, Eh value $-150 \mathrm{mV}$ or less leads to a significant $\mathrm{CH}_{4}$ production. A sharp decrease of Eh values were observed with increasing soil depth. Eh value decreased to $-250 \mathrm{mV}$ at $5 \mathrm{~cm}$ below soil surface within 7 DAI and same level maintained until the end of the incubation period. The results indicate that Eh value at $5 \mathrm{~cm}$ soil depth was favorable for $\mathrm{CH}_{4}$ formation. Observed soil $\mathrm{pH}$ values showed slightly alkaline soil condition over the incubation period irrespective of treatments. Neutral to slightly alkaline $\mathrm{pH}$ is beneficial for growth aquatic earthworm (Lou et al., 2013). Table 2 also shows total-C and total-N data of 35 DAI. Total-C ranges from 18.39 $\mathrm{g} \mathrm{kg}^{-1}$ in only earthworm treated soil to $19.52 \mathrm{~g} \mathrm{~kg}^{-1}$ in control treatment (NW NU). However, difference of total-C is not significant among the treatments. Total- $\mathrm{N}$ content also showed similar trend. $\mathrm{CN}$ ratio was $25: 1$. It implies that the soil has almost perfect balance of carbon to nitrogen for soil microbial growth. USDA (2011) reported that $\mathrm{CN}$ ratio $24: 1$ is favourable for soil microorganism.

Table 1. The Soil Eh at different depth during incubation period

\begin{tabular}{|c|c|c|c|c|c|c|c|c|c|c|c|c|}
\hline \multirow{3}{*}{ Treatments } & \multicolumn{6}{|c|}{ Eh at $1 \mathrm{~cm}$ depth $(\mathrm{mV})$} & \multicolumn{6}{|c|}{ Eh at $5 \mathrm{~cm}$ depth $(\mathrm{mV})$} \\
\hline & \multicolumn{6}{|c|}{ DAI } & \multicolumn{6}{|c|}{ DAI } \\
\hline & 0 & 7 & 14 & 21 & 28 & 35 & 0 & 7 & 14 & 21 & 28 & 35 \\
\hline EW UR & -38 & -45 & -51 & -53 & -57 & -60 & -41 & -258 & -240 & -235 & -252 & -242 \\
\hline EW NU & -35 & -45 & -48 & -50 & -57 & -62 & -38 & -252 & -247 & -232 & -246 & -237 \\
\hline NW UR & -35 & -44 & -54 & -58 & -64 & -67 & -37 & -240 & -230 & -230 & -254 & -249 \\
\hline NW NU & -38 & -48 & -56 & -62 & -66 & -73 & -40 & -244 & -236 & -228 & -247 & -245 \\
\hline
\end{tabular}

Table 2. The Soil properties during incubation period

\begin{tabular}{|c|c|c|c|c|c|c|c|c|c|c|c|c|}
\hline \multirow{2}{*}{ Days } & \multicolumn{4}{|c|}{$\mathrm{pH}$} & \multicolumn{4}{|c|}{ Soil total $\mathrm{C}\left(\mathrm{g} \mathrm{kg}^{-1}\right)$} & \multicolumn{4}{|c|}{ Soil total $\mathrm{N}\left(\mathrm{g} \mathrm{kg}^{-1}\right)$} \\
\hline & EW UR & EW NU & NW UR & NW NU & EW UR & EW NU & NW UR & NW NU & EW UR & EW NU & NW UR & NW NU \\
\hline 0 & 7.16 & 7.17 & 7.17 & 7.21 & 18.78 & 18.37 & 18.4 & 18.47 & 1.43 & 1.34 & 1.61 & 1.7 \\
\hline 7 & 7.44 & 7.48 & 7.44 & 7.47 & - & - & - & - & - & - & - & - \\
\hline 14 & 7.47 & 7.41 & 7.35 & 7.31 & - & - & - & - & - & - & - & - \\
\hline 21 & 7.48 & 7.42 & 7.39 & 7.35 & - & - & - & - & - & - & - & - \\
\hline 28 & 7.61 & 7.56 & 7.52 & 7.52 & - & - & - & - & - & - & - & - \\
\hline 35 & 7.51 & 7.42 & 7.29 & 7.29 & 18.89 & 18.39 & 18.41 & 18.52 & 1.44 & 1.37 & 1.62 & 1.71 \\
\hline
\end{tabular}




\subsection{Effect of Urea Fertilizer on Abundance of Branchiura Sowerbyi}

Figure 1 shows abundance of Branchiura sowerbyi in the soil received both treatments (earthworm + Urea) and in the soil received only earthworm treatment at 35 DAI. The data clearly shows that urea application was beneficial for growth of Branchiura sowerbyi during the incubation period. Average density of Branchiura sowerbyi was approximately $4050 / \mathrm{m}^{2}$ in earthworm inoculated and urea treated soils. Whereas, the density of Branchiura sowerbyi in soil without receiving urea was $2400 / \mathrm{m}^{2}$. The result indicated that applying urea at rate of $90 \mathrm{~kg} \mathrm{~N} \mathrm{ha}^{-1}$ was beneficial for growth of Branchiura sowerbyi in paddy field soil. Previous studies reported that low dose of urea is beneficial for aquatic earthworms (Xiao et al., 2004; Bhattacharya \& Sahu, 2014).

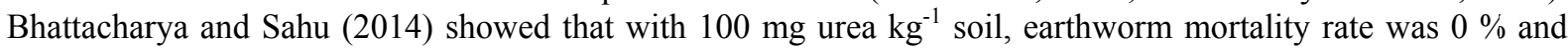
gradually the mortality rate was increased with increase of urea dose. In our study urea dose was very limited and it was $0.00012 \mathrm{mg}$ urea $\mathrm{kg}^{-1}$ soil which increased Branchiura sowerbyi density in soil. Therefore, further study is required to identify optimal dose of urea that is beneficial for Branchiura sowerbyi.

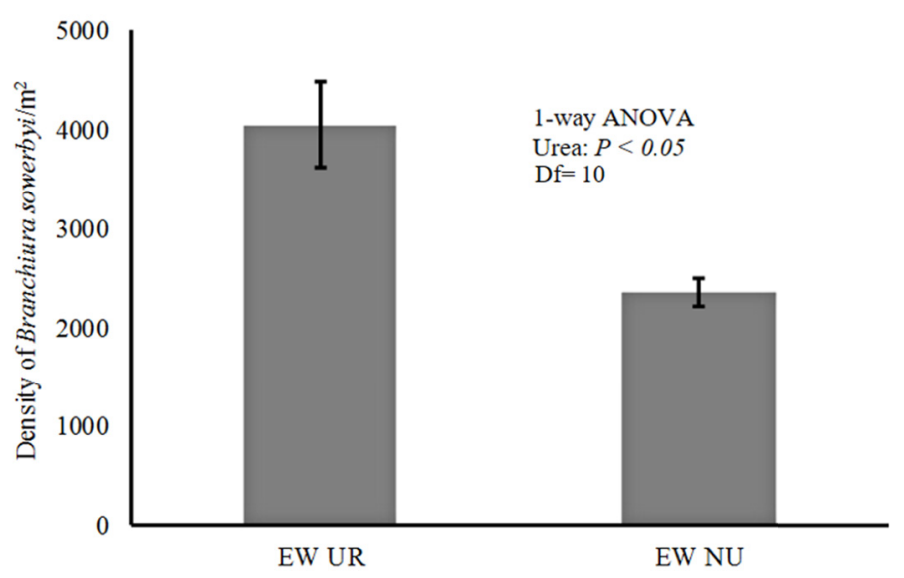

Figure 1. Influence of urea fertilizer on abundance of Branchiura sowerbyi in paddy field soil

Note. Vertical bars indicate standard error of mean.

\subsection{Influence of Branchiura Sowerbyi and Urea Fertilizer on $\mathrm{CH}_{4}$ Flux}

A clear increase in $\mathrm{CH}_{4}$ flux from 7 DAI was observed and reached to peak at 28 DAI, irrespective of treatments, except EW NU treatment, where the peak was at $21 \mathrm{DAI}$ (Figure 2). At $28 \mathrm{DAI}$ the highest $\mathrm{CH}_{4}$ flux $(2055 \mathrm{mg}$ $\mathrm{m}^{-2} \mathrm{~h}^{-1}$ ) was measured from soil received only urea without earthworm inoculation followed by $1378 \mathrm{mg} \mathrm{m}^{-2} \mathrm{~h}^{-1}$ in soil without receiving earthworm and urea. The results indicated urea application in paddy soil might increase $\mathrm{CH}_{4}$ emission. In previous studies (Wang et al., 1992; Banik et al., 1996; Yang \& Chang, 1997; Dubey, 2003) showed that urea increased $\mathrm{CH}_{4}$ production from anaerobic soil; they also observed a direct relationship among $\mathrm{CH}_{4}$ production, lower Eh values and higher $\mathrm{pH}$ levels in a flooded paddy soil. After urea is applied to paddy soils, it is hydrolyzed by microbial ureases, resulting in an alkaline soil $\mathrm{pH}$ and lowering the soil Eh. However, in our study, when paddy field soil received both urea and Branchiura sowerbyi, $\mathrm{CH}_{4}$ flux was reduced significantly, which was nearly 5 times less than that of soil with only urea treatment. Figure 1 in the earlier section showed that urea application at $90 \mathrm{~kg} \mathrm{~N}^{-1}$ rate stimulated density of Branchiura sowerbyi in paddy field. As a result, bioturbation activities increased, which might lead to increase penetration of oxygen in soil layer. These phenomena combinedly contributed to increase methanotrophs activities in paddy filed, consequently lower $\mathrm{CH}_{4}$ flux. Although, the lowest $\mathrm{CH}_{4}$ flux $\left(120 \mathrm{mg} \mathrm{m}^{-2} \mathrm{~h}^{-1}\right)$ without urea fertilizer in Branchiura sowerbyi inoculated soil, fertilizer application was required to get paddy yield at a satisfactory level. Therefore, we suggest future research should focus on optimization of urea rate that will be beneficial for earthworm growth and $\mathrm{CH}_{4}$ oxidation without compromising satisfactory level of crop yield. 


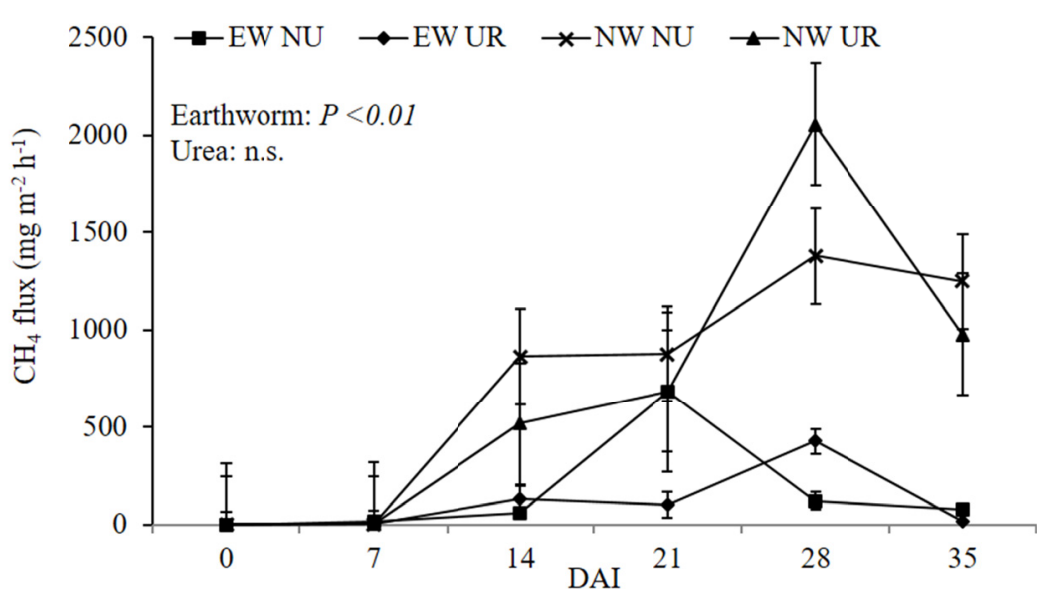

Figure 2. The effect of Branchiura sowerbyi and urea application on $\mathrm{CH}_{4}$ flux

Note. Vertical bars indicate standard error of mean.

During the incubation period, there was no significant effect of urea on $\mathrm{CH}_{4}$ flux, but the presence of urea increased the abundance of aquatic earthworms. The highest cumulative $\mathrm{CH}_{4}$ emission was observed in the NW-UR treatment $\left(18.0 \mathrm{~g} \mathrm{~m}^{-2} \mathrm{day}^{-1}\right)$ and the lowest were in the EW-UR treatment $\left(3.2 \mathrm{~g} \mathrm{~m}^{-2}\right.$ day $\left.^{-1}\right)$. Aquatic earthworms significantly $(\mathrm{P}<0.01)$ decreased the $\mathrm{CH}_{4}$ emissions after 35 days of incubation. On day 35 , in the treatment where the aquatic earthworm density decreased to 1684 earthworms $\mathrm{m}^{-2}$, the $\mathrm{CH}_{4}$ flux was $116 \mathrm{mg} \mathrm{m}^{-2}$ $\mathrm{h}^{-1}$, but in the treatment where the aquatic earthworm density increased to 5471 earthworms $\mathrm{m}^{-2}$, the $\mathrm{CH}_{4}$ flux was only $5.32 \mathrm{mg} \mathrm{m}^{-2} \mathrm{~h}^{-1}$. Branchiura sowerbyi is buried in the soil for feeding, while its tail remains on the surface for respiration; through this bioturbation activity Branchiura sowerbyi can introduce $\mathrm{O}_{2}$-rich water into the lower soil layers and it also produces a layer of fecal pellets on the soil surface. This modification of the soil habitat might lead to an increase in the biomass of methanotrophs, which accelerated the oxidation of $\mathrm{CH}_{4}$ produced by the methanogens. There are some previous studies which confirmed that macropores which are created through burrowing of earthworms and oxygenating water by bioturbation (Fox \& Taylor, 1955), earthworms diffuse $\mathrm{O}_{2}$ to the burrow linings and casts which is favorable microsite for methanogens and from these anoxic microsites $\mathrm{CH}_{4}$ would be consumed by methanotrophs which are available in relatively $\mathrm{O}_{2}$-rich habitat (Kernecker et al., 2015).

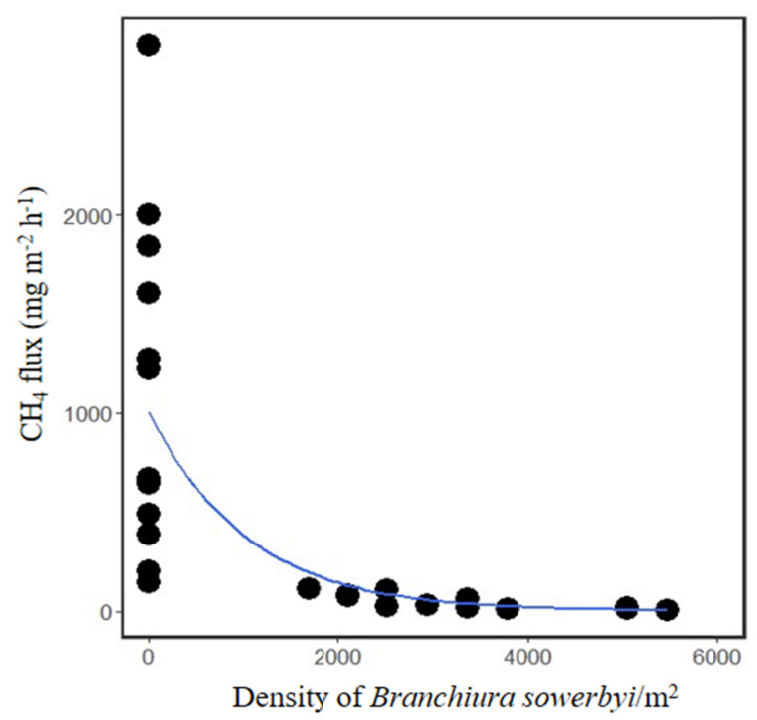

Figure 3. Relation between density of Branchiura sowerbyi and $\mathrm{CH}_{4}$ emission at $35 \mathrm{DAI}$ 


\subsection{Aquatic Earthworms and Biomass of Methanotrophs}

The PLFA profile in the soils is shown in Figure 4. Methanotrophs were dominant in the earthworm-treated soils, whereas Gram-positive bacteria were dominant in the soils where there were no earthworms (Figure 4a). The amount of PLFAs was compared among treatments to estimate the biomass of methanotrophs (Figure 4b).

(a)

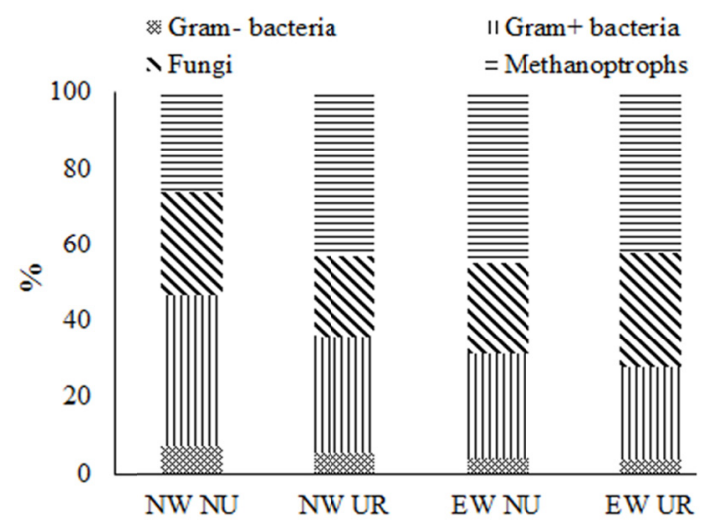

(b)

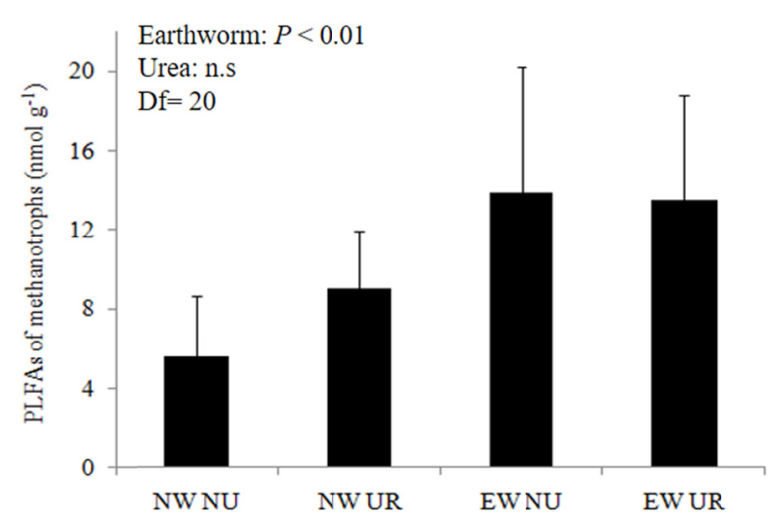

Figure 4. The composition of soil microbes and biomass with methanotrophs in the incubated paddy soil at $35 \mathrm{DAI}$

Note. Vertical bars indicate standard error of mean.

The highest biomass levels of methanotrophs, based on the PLFAs contents, were measured in the EW-NU and EW-UR treatments (13.8 and $13.5 \mathrm{nmol} \mathrm{^{-1 }}$, respectively) and the lowest levels were observed in the NW-NU treatment $\left(5.61 \mathrm{nmol} \mathrm{g}^{-1}\right)$. The results of the GLM confirmed that the presence of aquatic earthworms affected the biomass of methanotrophs $(\mathrm{P}<0.001)$, whereas urea did not have any significant effect. Increasing biomass of methanotrophs translated to reduction of the $\mathrm{CH}_{4}$ flux from the incubated soils $(\mathrm{P}<0.01)$ (Figure 5a). Figure $5 \mathrm{~b}$ implies that the presence of aquatic earthworms accelerates the growth of methanotrophs $(\mathrm{P}<0.001)$, which leads to reduction of the $\mathrm{CH}_{4}$ flux $(\mathrm{P}<0.01)$. Kernecker et al. (2015) also confirmed that the reduction of $\mathrm{CH}_{4}$ production rate in anoxic soil with the presence of earthworms is caused by methanotrophy which is stimulated by bioturbation activity of earthworms.
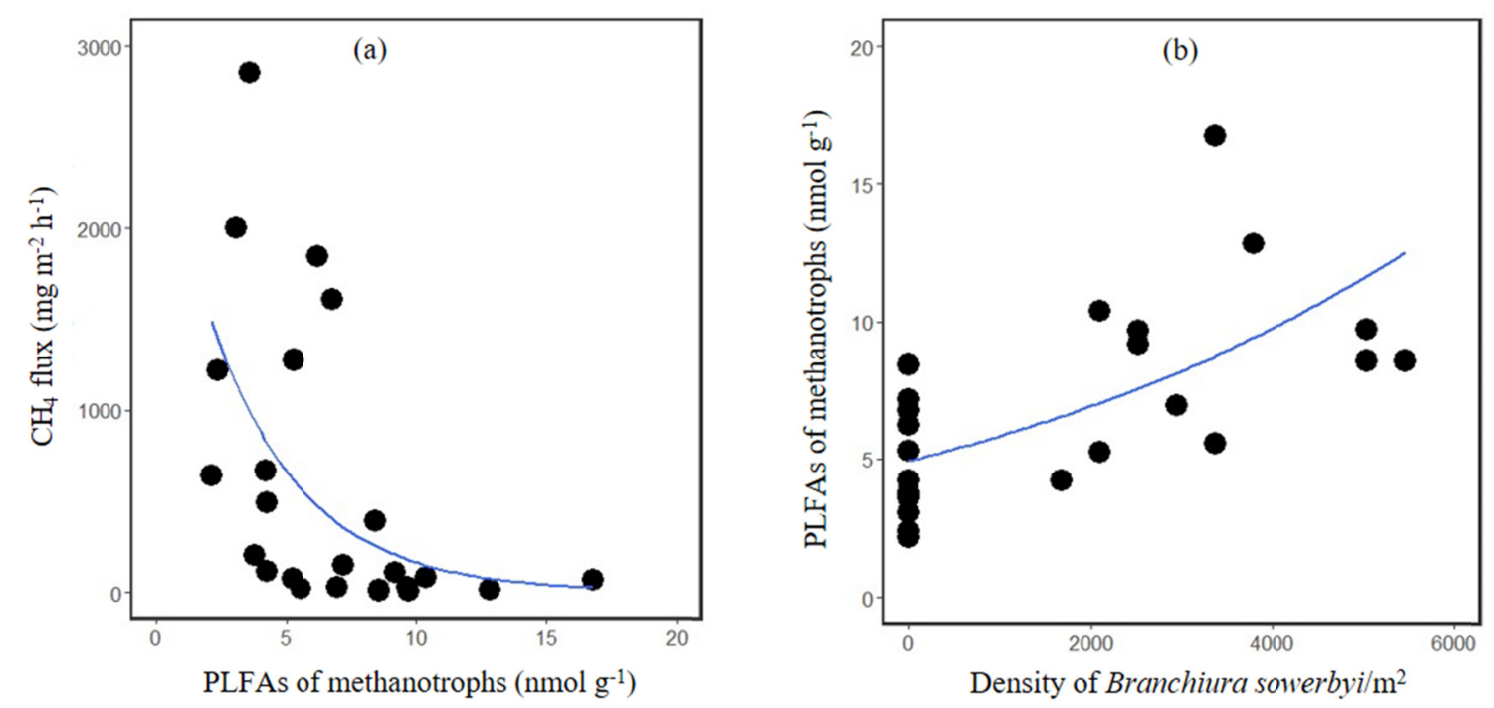

Figure 5. The relation between methanotrops and $\mathrm{CH}_{4}$ flux (a) and between Branchiura sowerbyi density and growth of methanotrophs (b) 
Results of GLM have been summarized in Table 3 and it implies: (i) increasing density of Branchiura sowerbyi has significant positive impact on growth of methanotrophs; (ii) increasing methanotrophs activity leads to significant $\mathrm{CH}_{4}$ emission reduction; and (iii) as a result Branchiura sowerbyi significantly contributes to mitigate $\mathrm{CH}_{4}$ in paddy soil environment.

Table 3. Parameter summary results of generalized linear model (GLM)

\begin{tabular}{lllll}
\hline Model & & Estimates & Std. error & P value \\
\hline $\mathrm{CH}_{4}$ emission $\sim$ Branchiura sowerbyi density & Intercept & 6.914 & $1.95 \mathrm{E}-01$ & $<0.001$ \\
& Branchiura sowerbyi & $-9.656 \mathrm{E}-04$ & $7.77 \mathrm{E}-05$ & $<0.001$ \\
\hdashline $\mathrm{CH}_{4}$ emission $\sim$ PLFA of methanotrophs & Intercept & 7.9 & & $<0.001$ \\
& PLFA of methanotrophs & -0.2796 & 0.07489 & $<0.01$ \\
of methanotrophs $\sim$ Branchiura sowerbyi density & Intercept & 1.59615 & 0.11192 & $<0.001$ \\
& Branchiura sowerbyi & 0.07169 & 0.01877 & $<0.001$ \\
\hline
\end{tabular}

\section{Conclusions}

Remarkable increase of atmospheric $\mathrm{CH}_{4}$ concentration over the centuries has puzzled climate scientists. Flooded rice cultivation has been blamed as one of the main sources of anthropogenic $\mathrm{CH}_{4}$ emission. Anaerobic methanogenesis is the main process of $\mathrm{CH}_{4}$ production in paddy field soil. It is obvious that wetland rice cultivation will be intensified to feed growing populations, which will also lead increasing contribution to atmospheric $\mathrm{CH}_{4}$ concentration, our findings showed that bioturbation of aquatic earthworms helps to reduce $\mathrm{CH}_{4}$ emission to the atmosphere by increasing methanotrophic activities in paddy field soil. Though earlier studies argued that urea application increases $\mathrm{CH}_{4}$ emission from paddy field, our study showed that in the presence of aquatic earthworms, urea fertilizer reduced $\mathrm{CH}_{4}$ emission by $90 \%$ by stimulating earthworm abundance in soil. Hence, it is important to conserve suitable environment for optimal growth of aquatic earthworms. We also recommend future research should focus on optimization of urea application rate that will be beneficial for earthworm growth and $\mathrm{CH}_{4}$ oxidation without compromising satisfactory level of crop yield.

\section{Acknowledgements}

We thank the non-profit organization Yamasaki Yato-No-Kai (Kamakura, Japan) for permitting us to collect soil for this experiment. We thank Dr. Yoshimichi Hanai (Center for Risk Management and Safety Sciences, Yokohama National University, Japan) for their technical support in the $\mathrm{CH}_{4}$ measurements; Dr. Yasushi Mori (Faculty of Agriculture and Forest Science, Shimane University, Japan) for their assistance with the soil texture analysis; and Prof. Akifumi Ohtaka (Faculty of Education, Hirosaki University, Japan) for identifying the species of aquatic earthworm.

\section{References}

Bates, D., Maechler, M., Bolker, B., \& Walker, S. (2015). Fitting linear mixed-effects models using lme4. Journal of Statistical Software, 67(1), 1-48. https://doi.org/10.18637/jss.v067.i01

Bhattacharya, A., \& Sahu, S. K. (2014). Lethal effect of urea on soil biota: A laboratory study on earthworm (Drawida willsi). J. Bio. \& Env. Sci., 4(6), 64-72.

Blasing, T. J. (2016). Recent greenhouse gas concentrations. Carbon dioxide Information Analysis Center. https://doi.org/10.3334/CDIAC/atg.032

Bodelier, P. L. E., Gillisen, M.-J. B., Hordijk, K., Damsté, J. S. S., Rijpstra, W. I. C., Geenevasen, J. A. J., \& Dunfield, P. F. (2009). A reanalysis of phospholipid fatty acids as ecological biomarkers for methanotrophic bacteria. The ISME Journal, 3(5), 606-617. https://doi.org/10.1038/ismej.2009.6

Bodelier, P. L., Roslev, P., Henckel, T., \& Frenzel, P. (2000). Stimulation by ammonium-based fertilizers of methane oxidation in soil around rice roots. Nature, 403(6768), 421-424. https://doi.org/10.1038/35000193

Bronson, K. F., Neue, H.-U., Abao, \& Singh, U. (1997). Automated chamber measurements of methane and nitrous oxide flux in a flooded rice soil: I. residue, nitrogen, and water management. Soil Sci. Soc. Am. J., 61, 981-987. https://doi.org/10.2136/sssaj1997.03615995006100030038x

Chen, G., Huang, G., Huang, B., et al. (1997). Nitrous oxide and methane emissions from soil-plant systems. Nutrient Cycling in Agroecosystems, 49, 41-45. https://doi.org/10.1023/A:1009758900629 
Depkat-Jakob, P. S., Hunger, S., Schulz, K., Brown, G. G., Tsai, S. M., \& Drake, H. L. (2012). Emission of methane by Eudrilus eugeniae and other earthworms from Brazil (pp. 3014-3019). https://doi.org/10.1128/ AEM.07949-11

Dubey, S. K. (2003). Spatio-kinetic variation of methane oxidizing bacteria in paddy soil at mid-tillering: Effect of N-fertilizers. Nutrient Cycling in Agroecosystems, 65(1), 53-59. https://doi.org/10.1023/A:102188 0915403

Dubey, S. K. (2005). Microbial ecology of methane emission in rice agroecosystem: A review. Applied Ecology and Environmental Research, 3(2), 1-27. https://doi.org/10.15666/aeer/0302

Fox, M. H., \& Taylor, A. E. R. (1955). The tolerance of oxygen by aquatic invertebrates. Phil Trans R Soc B, 143, 214-225. https://doi.org/10.1098/rspb.1955.0006

Frostegard, A., Baath, E., Frostegård, Å., \& Bååth, E. (1996). The use of phospholipid fatty acid analysis to estimate bacterial and fungal biomass in soil. Biology and Fertility of Soils, 22(1-2), 59-65. https://doi.org/ 10.1007/BF00384433

Frostegård, Å., Tunlid, A., \& Bååth, E. (1991). Microbial biomass measured as total lipid phosphate in soils of different organic content. Journal of Microbiological Methods, 14(3), 151-163. https://doi.org/10.1016/ 0167-7012(91)90018-L

Fukuhara, H., Kikuchi, E., \& Kurihara, Y. (1980). The effect of Branchiura sowerbyi (Tubificidae) on bacterial populations in submerged ricefield soil. Oikos, 34, 88-93. https://doi.org/10.2307/3544553

Gavin, S. (2004). Methane: A scientific journey from obscurity to climate super-stardom. National Aeronautics and Space Administration. Retrieved March 12, 2017, from http://www.giss.nasa.gov/research/features/ 200409 methane

Grant, I. F., \& Seegers, R. (1985). Tubificid role in soil mineralization and recovery of algal nitrogen by lowland rice. Soil Biology and Biochemistry, 17(4), 559-563. https://doi.org/10.1016/0038-0717(85)90025-2

Hanson, R. S., \& Hanson, T. E. (1996). Methanotrophic bacteria. Microbiological Reviews, 60(2), 439-471.

Inubushi, K., Hori, K., Matsnmoto, S., Umebayashi, M., \& Wada, H. (1989). Methane emission from the flooded paddy soil to the atmosphere through rice plant. Jpn. J. Soil Sci. Plant Nutr., 60, 318-324.

Jones, B. C. A., Koenig, R. T., Ellsworth, J. W., Brown, B. D., \& Jackson, G. D. (2013). Management of urea fertilizer to minimise volatilization. Montana State University Extension (pp. 1-12).

Jurasinski, G., Koebsch, F., Guenther, A., \& Beetz, S. (2014). Flux: Flux rate calculation from dunamic closed chamber measurements. $R$ Package Version 0.3-0. Retrieved March 12, 2017, from http://CRAN.R-project.org/package=flux

Kernecker, M., Whalen, J. K., \& Bradley, R. L. (2014). Endogeic earthworms lower net methane production in saturated riparian soils. Biology and Fertility of Soils, 51(2), 271-275. https://doi.org/10.1007/s00374014-0965-0

Kikuchi, E., \& Kurihara, Y. (1977). In vitro studies on the effects of tubificids on the biological, chemical and physical characteristics of submerged rice field soil and overlying water. Oikos, 29(2), 348-356. https://doi.org/10.2307/3543626

Kikuchi, E., \& Kurihara, Y. (1982). The effects of the oligochaete Branchiura sowerbyi Beddard (Tubificidae) on the biological and chemical characteristics of overlying water and soil in a submerged ricefield soil system. Hydrobiologia, 97(3), 203-208. https://doi.org/10.1007/BF00007108

Kimura, M., Asai, K., Watanabe, A., Murase, J., \& Kuwatsuka, S. (1992). Suppression of methane fluxes from flooded paddy soil with rice plants by foliar spray of nitrogen fertilizers. Soil Science and Plant Nutrition, 38(4), 735-740. https://doi.org/10.1080/00380768.1992.10416704

Kimura, M., Murase, J., \& Lu, Y. (2004). Carbon cycling in rice field ecosystems in the context of input, decomposition and translocation of organic materials and the fates of their end products $\left(\mathrm{CO}_{2}\right.$ and $\left.\mathrm{CH}_{4}\right)$. Soil Biology and Biochemistry, 36(9), 1399-1416. https://doi.org/10.1016/j.soilbio.2004.03.006

Kögel-Knabner, I., Amelung, W., Cao, Z., Fiedler, S., Frenzel, P., Jahn, R., \& Schloter, M. (2010). Biogeochemistry of paddy soils. Geoderma. Elsevier B.V. https://doi.org/10.1016/j.geoderma.2010.03.009

Lou, J., Cao, Y., Sun, P., \& Zheng, P. (2013). The effects of operational conditions on the respiration rate of tubificidae. PLoS ONE, 8(12), 1-9. https://doi.org/10.1371/journal.pone.0081219 
Lüdemann, H., Arth, I., \& Liesack, W. (2000). Spatial changes in the bacterial community structure along a vertical oxygen gradient in flooded paddy soil cores. Applied and Environmental Microbiology, 66(2), 754-762. https://doi.org/10.1128/AEM.66.2.754-762.2000

Minamikawa, K., Sakai, N., \& Hayashi, H. (2005). The effects of ammonium sulfate application on methane emission and soil carbon content of a paddy field in Japan. Agriculture, Ecosystems and Environment, 107(4), 371-379. https://doi.org/10.1016/j.agee.2004.10.027

Montzka, S. A., Dlugokencky, E. J., \& Butler, J. H. (2011). Non- $\mathrm{CO}_{2}$ greenhouse gases and climate change. Nature, 476(7358), 43-50. https://doi.org/10.1038/nature10322

Moore-Kucera, J., \& Dick, R. P. (2008). PLFA profiling of microbial community structure and seasonal shifts in soils of a Douglas-fir chronosequence. Microbial Ecology, 55(3), 500-511. https://doi.org/10.1007/ s00248-007-9295-1

Niwa, S., Kaneko, N., Okada, H., \& Sakamoto, K. (2008). Effects of fine-scale simulation of deer browsing on soil micro-foodweb structure and $\mathrm{N}$ mineralization rate in a temperate forest. Soil Biology and Biochemistry, 40(3), 699-708. https://doi.org/10.1016/j.soilbio.2007.10.004

Nouchi, I., Mariko, S., \& Aoki, K. (1990). Mechanism of methane transport from the rhizosphere to the atmosphere through rice plants. Plant Physiology, 94(1), 59-66. https://doi.org/10.1104/pp.94.1.59

Olsson, S., \& Alström, S. (2000). Characterisation of bacteria in soils under barley monoculture and crop rotation. Soil Biology and Biochemistry, 32(10), 1443-1451. https://doi.org/10.1016/S0038-0717(00) 00062-6

$\mathrm{R}$ Development Core Team. (2015). $R$ version 3.2.3: A language and environment for statistical computing. $\mathrm{R}$ foundation for statistical computing, Vienna, Austria. Retrieved from http://www.R-project.org

Shindell, D. T., Faluvegi, G., Koch, D. M., Schmidt, G. A., Unger, N., \& Bauer, S. E. (2009). Improved attribution of climate forcing to emissions. Interactions, 326(x), 716-718. https://doi.org/10.1126/ science. 1174760

Simpson, I. C., Roger, P. A., Oficial, R., \& Grant, I. F. (1993). Impacts of agricultural practices on aquatic oligochaete populations in ricefields. Biology and Fertility of Soils, 16(1), 27-33. https://doi.org/10.1007/ BF00336511

Smith, P., Martino, D., Cai, Z., Gwary, D., Janzen, H., Kumar, P., ... Miller, H. L. (2007). Climate change 2007: methane emissions from rice production in the United States. The Physical Science Basis (pp. 498-540). Contribution of working group I to the fourth assessment report of the intergovernmental panel on climate change. Cambridge: Cambridge University Press.

Soh, K. G. (2001). A review of the global fertilizer use by product. Retrieved from http://klimat.czn.uj.edu.pl/ documents/ACCENT/Edition08/textsmaterial/english/fertilizer_usage_2001.pdf

Takai, Y. (1970). The mechanism of methane fermentation in flooded paddy soil. Soil Science and Plant Nutrition, 16(6), 238-244. https://doi.org/10.1080/00380768.1970.10433371

Thauer, R. K. (1998). Biochemistry of methanogenesis: A tribute to Marjory Stephenson. Microbiology, 144, 2377-2406. https://doi.org/10.1099/00221287-144-9-2377

UNFCCC Secretariat. (2015). Paris Agreement, FCCC/CP/2015/L.9/Rev.1. December 12, 2015.

USDA Natural Resources Conservation Service. (2011). Carbon to nitrogen ratios in cropping systems. USDA NRCS East National Technology Support Center, Greensboro, NC, in cooperation with North Dakota NRCS.

Wang, Z., Delaune, R. D., Lindau, C. W., \& Junior, W. H. P. (1992). Methane production from anaerobic soil amended with rice straw and nitrogen fertilizers. Fertilizer Research, 33(2), 115-121. https://doi.org/ 10.1007/BF01051166

Watanabe, A., Takeda, T., \& Kimura, M. (1999). Evaluation of origins of $\mathrm{CH}_{4}$ carbon emitted from rice paddies. Journal of Geophysical Research, 104, 623-629. https://doi.org/10.1029/1999JD900467

Wilkinson, S. G. (1988). Gram-negative bacteria. Microbial Lipids, 1, 299-488.

Xiao, H., Zhou, Q. X., \& Liang, J. D. (2004). Single and joint effects of acetechlor and urea on earthworm Eisenia foetida population in Phaiozem. Environmental Geochemistry and Health, 26(2), $277-283$. https://doi.org/10.1023/B:EGAH.0000039591.36259.a1 
Yachi, S., Ohtaka, A., \& Kaneko, N. (2012). Community structure and seasonal changes in aquatic oligochaetes in an organic paddy field in Japan. Edaphologia, 90, 13-24.

Yagi, K., \& Minami, K. (1990). Effect of organic matter application on methane emission from some Japanese paddy fields. Soil Science and Plant Nutrition, 36(4), 599-610. https://doi.org/10.1080/00380768.1990. 10416797

Yao, H., Conrad, R., Wassmann, R., \& Neue, H. U. (1999). Effect of soil characteristics on sequential reduction and methane production in sixteen rice paddy soils from China, the Philippines, and Italy. Biogeochemistry, 47(3), 269-295. https://doi.org/10.1007/BF00992910

Yingst, J. Y., \& Rhoads, D. C. (1980). The role of bioturbation in the enhancement of bacterial growth rates in marine sediments. In K. R. Tenore, \& B. C. Coull (Eds.), Marine benthic dynamics (pp. 407-421). University of South Carolina Press, Columbia.

Zigah, P. K., Oswald, K., Brand, A., Dinkel, C., Wehrli, B., \& Schubert, C. J. (2015). Methane oxidation pathways and associated methanotrophic communities in the water column of a tropical lake. Limnology and Oceanography, 60(2), 553-572. https://doi.org/10.1002/lno.10035

\section{Copyrights}

Copyright for this article is retained by the author(s), with first publication rights granted to the journal.

This is an open-access article distributed under the terms and conditions of the Creative Commons Attribution license (http://creativecommons.org/licenses/by/4.0/). 